\title{
The Biomarker Salivary SP-D May Indicate Small Airway Inflammation and Asthma Exacerbation
}

\author{
Okazaki $\mathrm{S}^{* *}$, Murai $\mathrm{H}^{{ }^{*}}$, Kidoguchi $\mathrm{S}^{2}$, Nomura $\mathrm{E}^{1}$, Itoh $\mathrm{N}^{1}$, Hashimoto $\mathrm{N}^{2}$, \\ Hamada $T^{2}$, Kawakita $A^{1}$, Yasutomi $M^{1}$, Ohshima $Y^{1}$
}

*These authors contributed equally to the manuscript

'Department of Pediatrics, Faculty of Medial Sciences, University of Fukui, Fukui, Japan

2Department of Clinical Laboratory, Faculty of Medial Sciences, University of Fukui, Fukui, Japan

J Investig Allergol Clin Immunol 2017; Vol. 27(5): 305-312

doi: 10.18176/jiaci.0174

\begin{abstract}
Background: Noninvasive and child-friendly biomarkers are important tools for understanding the various phenotypes of childhood asthma. Objective: The aim of this study was to examine the usefulness of salivary surfactant protein (SP) D in assessing the pathophysiology of childhood asthma.

Methods: We measured salivary concentrations of SP-D and forced oscillation technique (FOT) indexes in 19 healthy controls and 21 asthmatic children. Regression equations for the predictive values of FOT indexes were generated from healthy controls. We analyzed the correlations between salivary SP-D concentration and percentages of the predictive values of FOT indexes, as well as the severity of exacerbation.

Results: We found that salivary SP-D levels were higher in asthmatic children than in healthy controls. In the asthmatic children, salivary SP-D levels correlated with the percentages of predicted differences in resistance between $5 \mathrm{~Hz}$ and $20 \mathrm{~Hz}$ (\%R5-R20), which represented the resistance of peripheral airways, and with the severity of asthma exacerbation.

Conclusion: Salivary SP-D may reflect asthmatic inflammation in peripheral small airways and may be a useful marker for monitoring the degree of exacerbation in childhood asthma.
\end{abstract}

Key words: Asthma. Biomarkers. Children. Forced oscillation technique. Salivary SP-D.

\section{Resumen}

Antecedentes: El empleo de biomarcadores no invasivos es una buena herramienta para estudiar la fisiopatología de los diferentes fenotipos del asma infantil.

Objetivo: El objetivo de este estudio fue examinar la utilidad de la proteína salival surfactante (SP) D en la evaluación de la fisiopatología del asma infantil.

Métodos: Se midieron las concentraciones en la saliva de SP-D y se realizaron oscilometrías forzadas de impulsos (FOT) en 21 niños asmáticos y 19 controles sanos. Las ecuaciones de regresión para los valores predictivos de los índices FOT se generaron a partir de controles sanos. Se analizaron las correlaciones entre la concentración de SP-D salival y los porcentajes de los valores predictivos de los índices FOT, así como la gravedad de las exacerbaciones.

Resultados: Se encontró que los niveles en la saliva de la SP-D fueron más elevados en los niños asmáticos en comparación con los controles sanos. En los niños asmáticos, los niveles de SP-D salival se correlacionaron con los porcentajes de las diferencias predichas en la resistencia entre $5 \mathrm{~Hz}$ y $20 \mathrm{~Hz}$ (\% R5-R20), que representan la resistencia de las vías respiratorias periféricas y la gravedad de la exacerbación del asma. Conclusión: La SP-D salival puede reflejar la inflamación asmática en las vías respiratorias pequeñas y puede ser un marcador útil para monitorizar el grado de exacerbación en el asma infantil.

Palabras clave: Asma. Biomarcadores. Niños. Oscilometría forzada de impulsos. Proteína salival surfactante D. 


\section{Introduction}

Bronchial asthma is a common chronic inflammatory airway disease in childhood and is defined by recurrent episodes of wheezing, chest tightness, breathlessness, and cough associated with reversible expiratory airflow limitation [1]. Asthma is a heterogeneous disorder, encompassing various phenotypes that can be categorized based on biomarkers such as induced sputum, exhaled nitric oxide, and lung function [2]. Owing to difficulties in the application of these biomarkers in young children [3], the heterogeneity of childhood asthma and its underlying pathophysiology remain to be clarified. Therefore, noninvasive and child-friendly biomarkers are required.

The forced oscillation technique (FOT) is a noninvasive method for measuring airway resistance and elastance during quiet tidal breathing [4-6]. Unlike spirometry, FOT does not require active cooperation or forced respiratory maneuvers and is thus more suitable for young children. FOT has been shown to be more sensitive than spirometry in identifying disturbances of peripheral airway function and has been successfully used for the assessment of pulmonary function in children who cannot perform spirometry during asthma attacks [7-9]. However, various factors, including age, sex, height, and weight, are known to influence FOT parameters [10-13]. Therefore, standardization of FOT indexes with reference values is essential for accurate data acquisition.

Surfactant protein D (SP-D) is a collectin family molecule that, as a component of the innate immune system, plays an important role in pulmonary host defense [14]. The C-terminal lectin head of SP-D suppresses inflammatory cell activation, whereas the N-terminal collagen tail stimulates dendritic cells and macrophages to phagocytose pathogens and apoptotic cells. SP-D also binds to several allergens, thereby modifying allergic responses in the lung [15-17]. In murine asthma models, SP-D attenuates allergen-induced eosinophilia and $\mathrm{T}_{\mathrm{H}} 2$ cytokine production, resulting in suppression of airway hyper-responsiveness and remodeling [18]. SP-D levels in bronchoalveolar lavage fluid (BALF) have been shown to correlate with the severity of asthma, airway smooth muscle mass, and reticular basement membrane thickness [19]; serum SP-D concentrations are associated with the degree of bronchial inflammation in allergic patients.

SP-D is secreted from the salivary glands, as well as from type II alveolar epithelial cells and nonciliated Clara cells. $[19,20]$. Of note, glandular tissues in the minor salivary glands of asthmatics exhibit airway-like inflammation [21]. We took advantage of this fact to develop an easy and noninvasive method of sampling SP-D in the saliva of young children. Salivary levels of SP-D were then correlated with FOT indexes and clinical symptoms. We found that salivary SP-D levels correlated with both peripheral airway resistance and severity of asthma exacerbation.

\section{Methods}

\section{Participants}

We enrolled 21 asthmatic children and 19 healthy controls in the study, which was performed at University of Fukui
Hospital, Fukui, Japan between 2012 and 2014. Asthmatic patients were diagnosed by board-certified allergists based on either of the following criteria: more than 3 episodes of wheeze within the previous year; or a hospital admission due to respiratory failure and wheeze within the previous year. Children who had a history of cardiovascular disease, perinatal abnormality, pulmonary infectious disease, and/or immunodeficiency were excluded. The severity of an acute asthma attack was assessed using the acute asthma intensity research score (AAIRS) [22]. The controls were healthy children who had undergone preoperative evaluations and in whom asthma and other respiratory diseases had been ruled out. After written informed consent was obtained from the guardians, saliva was collected using the SalivaBio Children's Swab (Salimetrics) according to the manufacturer's protocol. Briefly, one end of the swab was placed under the participant's tongue for 5 minutes. The saturated swabs were inserted into the swab storage tube and centrifuged at $1200 \mathrm{rpm}$ for 7 minutes at $4{ }^{\circ} \mathrm{C}$. Samples $(1-2 \mathrm{~mL})$ were then stored at $-80^{\circ} \mathrm{C}$ until salivary SP-D was measured. Saliva was collected at least 2 hours after the last meal. The study was approved by the review board of the University of Fukui Hospital (IRB 20120117).

\section{Forced Oscillation Technique}

Airway resistance at $5 \mathrm{~Hz}$ and $20 \mathrm{~Hz}(\mathrm{R} 5, \mathrm{R} 20)$, reactance at $5 \mathrm{~Hz}$ (X5), resonant frequency (Fres), and area of low reactance (ALX) were measured using Mostgraph-01 (Chest Co.). Mostgraph-01 continuously measures respiratory parameters during the whole breath, as well as during the inspiratory and expiratory phases, and detects changes in oscillation frequencies. FOT measurements were taken at the time of saliva collection with the participant in the upright position and wearing a nose clip. During the measurements, the participant's cheeks were supported by the hands of investigators.

\section{Salivary SP-D Measurement}

Salivary SP-D concentrations were measured using ELISA (SP-D DuoSet, R\&D Systems) according to the company's protocol. Briefly, 96-well ELISA plates (AGC Techno Glass Co.) were coated with $100 \mu \mathrm{L} /$ well of $2 \mu \mathrm{g} / \mathrm{mL}$ capture antibody. After blocking with PBS/1\%BSA, $50 \mu \mathrm{L}$ of standard samples in $\mathrm{PBS} / 1 \% \mathrm{BSA}$ or nondiluted salivary samples were added to each well. After washing with $\mathrm{PBS} / 0.05 \%$ Tween 20 , the plates were incubated with $100 \mu \mathrm{L} /$ well of $0.5 \mu \mathrm{g} / \mathrm{mL}$ detection antibody, and then with $100 \mu \mathrm{L} /$ well of horseradish peroxidase-conjugated streptavidin $(\times 4000$ in PBS/1\% BSA). The plates were developed with tetramethylbenzidine peroxidase substrate solution.

\section{Regression Equations for the Predictive Values of FOT Indexes}

Linear regression equations for the predicted values of FOT indexes were generated from data collected from the 19 healthy controls. The percentages of predicted FOT values in the asthmatic patients were calculated using regression equations, with age, height, and weight as independent variables. 
Table 1. Demographics and Clinical Characteristics of Study Patients

\begin{tabular}{|c|c|c|c|}
\hline & Controls & Asthmatics & Asthmatics Followed-up \\
\hline No. & 19 & 21 & 7 \\
\hline Age, y (range) & $10(5-14)$ & $8(5-11)$ & $7(5-11)$ \\
\hline Male-to-female ratio & $10: 9$ & $13: 8$ & $5: 2$ \\
\hline Weight, kg (range) & $33.9(14.9-76)$ & $26.3(17.7-48.6)$ & $19.3(17.1-45.8)$ \\
\hline Height, cm (range) & $140.1(104.4-168)$ & $128(104-140.6)$ & $116(104-144)$ \\
\hline \multicolumn{4}{|l|}{ Controller } \\
\hline None & 0 & 5 & 1 \\
\hline LTRA alone & 0 & 2 & 0 \\
\hline ICS+LTRA & 0 & 7 & 4 \\
\hline ICS/LABA & 0 & 1 & 1 \\
\hline ICS/LABA+LTRA & 0 & 6 & 1 \\
\hline \multicolumn{4}{|l|}{ Asthma severity (GINA) } \\
\hline Mild/moderate/severe & NA & $14 / 6 / 1$ & $4 / 2 / 1$ \\
\hline $\begin{array}{l}\text { No. of patients with } \\
\text { acute asthmatic attack(s) }\end{array}$ & 0 & 12 & 7 \\
\hline AAIRS of children with asthmatic attack & NA & $2(1-13)$ & $4(1-13)$ \\
\hline
\end{tabular}

Abbreviations: AAIRS, acute asthma intensity research score; GINA, Global Initiative for Asthma 2016; ICS, inhaled corticosteroid; LTRA, leukotriene receptor antagonist; LABA, long-acting B-agonist; NA, not applicable.

\section{Statistical Analysis}

The data are presented as median (range). Unpaired $t$ tests and the Wilcoxon signed-rank test were used to compare salivary SP-D levels between asthmatic patients and healthy controls and to analyze changes in salivary SP-D levels during asthma exacerbations. Correlations between salivary SP-D values and FOT parameters were evaluated using the nonparametric Spearman rho test. A $P$ value $<.05$ was considered statistically significant.

\section{Results}

\section{Baseline Characteristics of Healthy Controls and Asthmatic Children}

We enrolled 19 healthy controls (male:female, 10:9) and 21 asthmatic children (male:female, 13:8) in the study. The median age was 10 years (range, 5-14 years) in healthy controls and 8 years (range, 5-11 years) in asthmatic patients (Table 1). Sixteen out of 21 asthmatic children were treated with controller medications, and no patients received regular therapy with systemic corticosteroids. According to the Global Initiative for Asthma (GINA) 2016 criteria [23], 14 patients had mild persistent asthma, 6 had moderate persistent asthma, and 1 had severe persistent asthma,. Salivary samples were obtained during an acute asthma attack and during the followup convalescent period in 7 out of 12 patients who had had at least 1 asthma exacerbation during the study period.

\section{Multivariable Regression Equations for Predicted Values of FOT Indexes}

Asthmatic children demonstrated higher FOT indices, with the exception of X5, than controls (Table 2). Previous studies have reported an inverse relationship between resistances and height. More recently, associations between FOT indexes and other growth-associated factors, such as weight and age, have also been demonstrated [12]. Thus, differences in the FOT indices might be due to differences in growth-associated factors between asthmatics and controls rather than to the presence or absence of asthma. Furthermore, FOT percentages appear to be more useful biomarkers than absolute FOT values.

Since growth-associated factors do not necessarily correlate with each other, we generated multiple variable regression equations to predict R5, R20, R5-R20, X5, Fres, and ALX values as dependent variables using the age, height, and weight of the healthy controls as independent variables (Table 3). The multivariable regression equations for the various parameters in a whole breath demonstrated higher $\mathrm{R}^{2}$ values and coefficients of determination than for those in the expiratory and inspiratory phases (data not shown). Thus, the predictive values of R5, R20, R5-R20, X5, Fres, and ALX in a whole breath were used in the subsequent analysis.

Table 2. Absolute Values of Forced Oscillation Technique Indexes in Healthy Controls and Asthmatics

\begin{tabular}{lcc} 
& Controls & Asthmatics \\
\hline $\mathrm{R} 5\left(\mathrm{~cm} \mathrm{H}_{2} \mathrm{O} / \mathrm{L} / \mathrm{s}\right)$ & $5.04(3.42-6.54)$ & $6.26(4.61-7.59)$ \\
$\mathrm{R} 20(\mathrm{~cm} \mathrm{H} 2 \mathrm{O} / \mathrm{L} / \mathrm{s})$ & $3.70(2.69-4.84)$ & $4.49(3.38-5.92)$ \\
$\mathrm{R} 5-\mathrm{R} 20\left(\mathrm{~cm} \mathrm{H} \mathrm{H}_{2} \mathrm{O} / \mathrm{L} / \mathrm{s}\right)$ & $1.19(0.49-1.76)$ & $1.6(1.04-2.47)$ \\
$\mathrm{X} 5\left(\mathrm{~cm} \mathrm{H} \mathrm{H}_{2} \mathrm{O} / \mathrm{s}\right)$ & -1.63 & -2.48 \\
& $(-1.87$ to -0.65$)$ & $(-3.97$ to -1.46$)$ \\
Fres $(\mathrm{Hz})$ & $12.49(10.6-15.98)$ & $15.78(12.42-17.1)$ \\
ALX $\left(\mathrm{cm} \mathrm{H} \mathrm{H}_{2} \mathrm{O} / \mathrm{L} / \mathrm{s} \times \mathrm{Hz}\right)$ & $8.31(2.66-13.22)$ & $14.77(7.2-30.40)$
\end{tabular}

Abbreviations: ALX, area of low reactance; Fres, resonant frequency; R5 and $\mathrm{R} 20$, airway resistance at $5 \mathrm{~Hz}$ and $20 \mathrm{~Hz} ; \mathrm{X} 5$, reactance at $5 \mathrm{~Hz}$. avalues expressed as median (IQR). 
Table 3. Regression Equations for Predictive Values of Forced Oscillation Technique Indexes

\begin{tabular}{|c|c|c|c|c|c|c|c|}
\hline & & R5 & $\mathrm{R} 20$ & R5-R20 & $\mathrm{X} 5$ & Fres & ALX \\
\hline \multirow[t]{3}{*}{ Age } & Coef. & -0.4 & -0.3 & -0.067 & 0.065 & -0.33 & -0.509 \\
\hline & $\beta$ & -0.66 & -0.9 & -0.234 & 0.145 & -0.185 & -0.129 \\
\hline & $p$ & 0.24 & 0.14 & 0.75 & 0.82 & 0.75 & 0.83 \\
\hline \multirow[t]{3}{*}{ Height } & Coef. & -0.04 & 0 & -0.041 & 0.067 & -0.278 & -0.672 \\
\hline & $\beta$ & -0.47 & 0.01 & 0.7 & -0.496 & -1.084 & 0.616 \\
\hline & $p$ & 0.59 & 0.99 & 0.4 & 0.3 & 0.25 & 0.23 \\
\hline \multirow{3}{*}{ Weight } & Coef. & 0.037 & 0 & 0.035 & -0.039 & 0.169 & 0.428 \\
\hline & $\beta$ & 0.345 & 0.02 & -0.999 & 1.049 & 0.537 & -1.19 \\
\hline & $p$ & 0.48 & 0.14 & 0.75 & 0.38 & 0.31 & 0.26 \\
\hline \multirow[t]{2}{*}{ Intercept } & Coef & 13.18 & 6.83 & 6.347 & -10.15 & 48.832 & 93.415 \\
\hline & $p$ & 0.04 & 0.09 & 0.11 & 0.06 & 0.02 & 0.04 \\
\hline \multirow{5}{*}{\multicolumn{2}{|c|}{$\begin{array}{l}\text { Regression equations } \\
\text { for the predicted values }\end{array}$}} & $\mathrm{R} 5=$ & $\mathrm{R} 20=$ & $\mathrm{R} 5-\mathrm{R} 20=$ & $\mathrm{X} 5=$ & Fres $=$ & $\mathrm{ALX}=$ \\
\hline & & 13.175 & 6.828 & 6.347 & -10.153 & 48.832 & 93.415 \\
\hline & & $-0.395 x A$ & $+0.328 \times \mathrm{A}$ & $-0.067 \times A$ & $+0.065 \mathrm{xA}$ & $-0.330 \mathrm{xA}$ & $-0.509 \times A$ \\
\hline & & $-0.041 \times H$ & $+0.001 \mathrm{x}$ & $-0.041 \times \mathrm{xH}$ & $+0.067 \mathrm{xH}$ & $-0.278 \times \mathrm{xH}$ & $-0.672 \times H$ \\
\hline & & $+0.037 \mathrm{xW}$ & $+0.001 \mathrm{xW}$ & $+0.035 \mathrm{xW}$ & $-0.039 \mathrm{xW}$ & $+0.169 \mathrm{xW}$ & $+0.428 \mathrm{xW}$ \\
\hline \multicolumn{2}{|c|}{ Adjusted R2 } & 0.61 & 0.61 & 0.31 & 0.49 & 0.56 & 0.53 \\
\hline
\end{tabular}

Abbreviations: ALX, area of low reactance; Fres, resonant frequency; R5 and R20, airway resistance at $5 \mathrm{~Hz}$ and $20 \mathrm{~Hz} ; \mathrm{X} 5$, reactance at $5 \mathrm{~Hz}$.

\section{Salivary SP-D Levels Correlate With R5-R20 in Asthmatic Children}

SP-D levels in BALF and serum have been shown to reflect the degree of bronchial inflammation in asthmatics $[14,24]$. Salivary SP-D levels in asthmatics were higher than in healthy controls $(P<.05)$ (Figure 1). However, we observed no correlation between salivary SP-D levels and the use of leukotriene receptor antagonists $(P=.1268)$ or inhaled corticosteroids $(P=.2187)$.

We next analyzed the correlation between salivary SP-D levels and the percentage of predicted values of the FOT index in all 21 asthmatic children. As shown in Figure 2, salivary SP-D concentrations correlated positively with the percentage

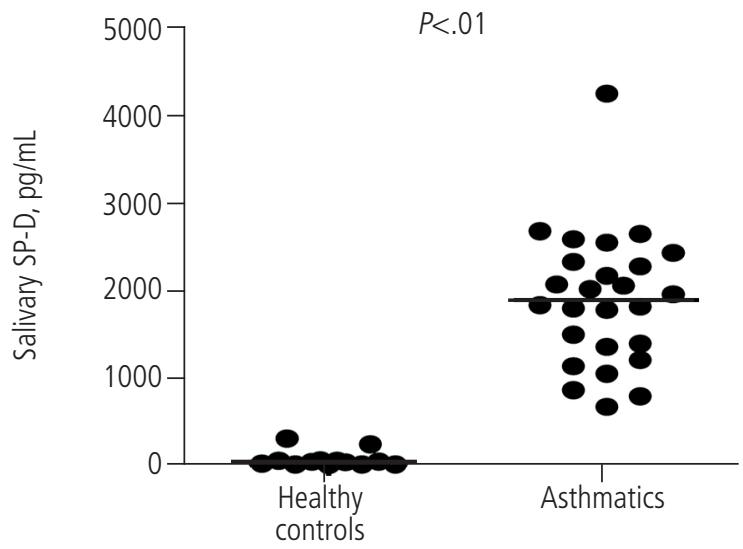

Figure 1. Salivary SP-D levels in asthmatic children were higher than those in healthy controls. SP indicates surfactant protein. of predicted R5-R20 values $(P<.05)$. None of the other FOT indexes were significantly associated with salivary SP-D levels.

\section{Salivary SP-D Concentrations Increased During Acute Asthma Attacks}

Shi et al [25] demonstrated that increased peripheral airway indexes of FOT, including R5-R20 and ALX, predict asthma exacerbation. We thus asked whether salivary SP-D levels were associated with the severity of an acute asthma attack, as assessed by AAIRS [22]. As shown in Figure 3A, there was no significant correlation between salivary concentrations of SP-D and AAIRS. However, in each asthmatic child, the SP-D concentrations during an acute asthma attack were higher than during the convalescent period, suggesting that individual changes in salivary SP-D levels reflect a change in asthma severity (Figure 3B). The changes in salivary SP-D levels associated with asthma exacerbation were similar to those observed in other patients who were not originally recruited in this study (data not shown).

\section{Discussion}

We generated regression equations for the predicted values of FOT indexes in Japanese children and demonstrated that salivary SP-D levels increased during asthma exacerbations and correlated positively with \%R5-R20, a peripheral airway index of FOT. Thus, salivary SP-D might serve as a noninvasive biomarker for monitoring peripheral airway function and exacerbations of childhood asthma.

Previous studies have demonstrated that height is the most significant predictor of all FOT indexes in children; 
neither gender nor race appears to be an important covariate $[10,11,13]$. In this study, age had the largest absolute $\beta$ value among the independent variables of the regression equations, indicating that it was the most influential predictive variable of almost all FOT indexes. The limited number of normal healthy controls in our study might explain this discrepancy. Since height and weight have also been shown to influence the regression equations in many FOT indexes, we generated
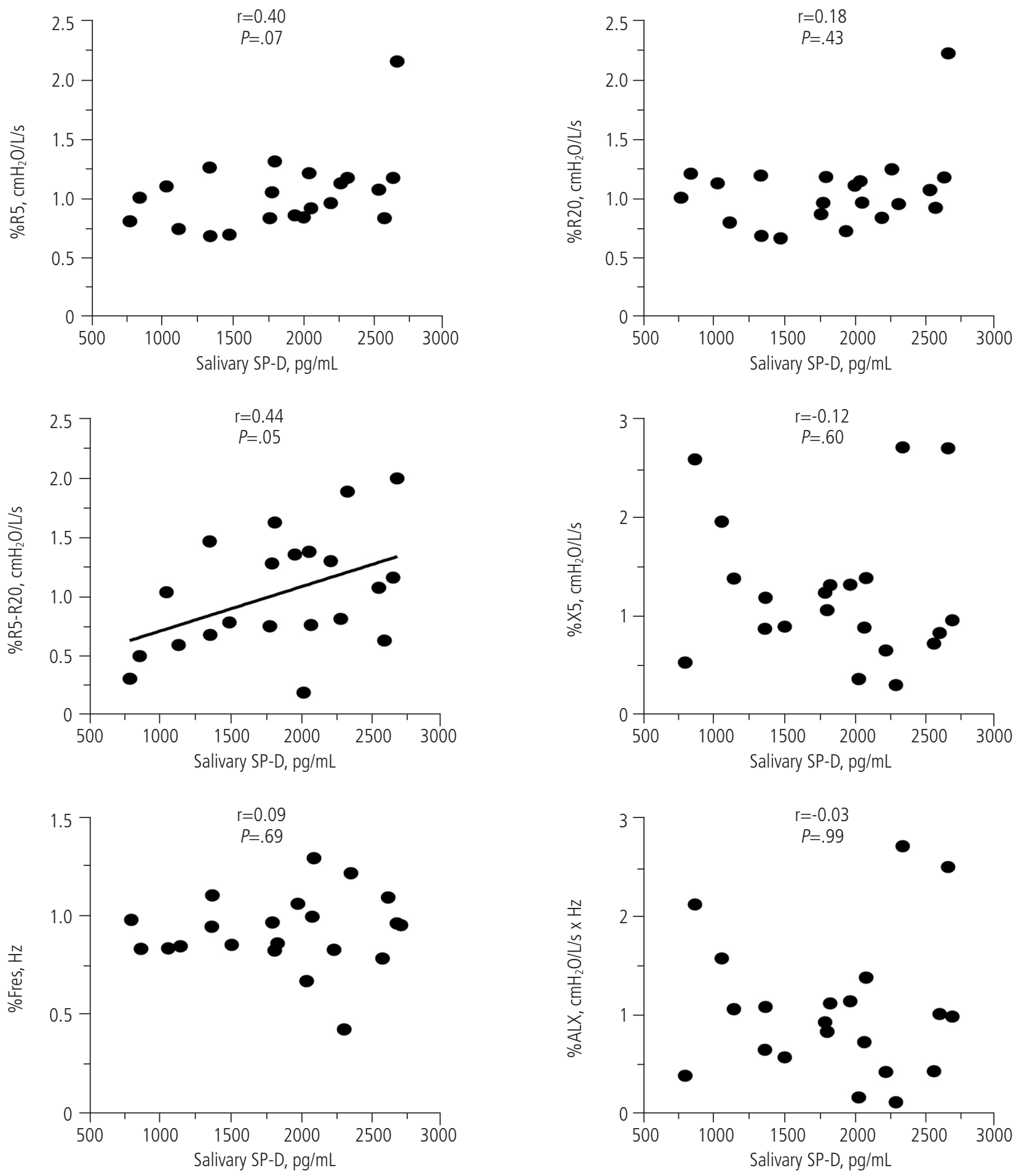

Figure 2. Correlations between salivary SP-D levels and the percentages of predicted values of forced oscillatory technique indexes in asthmatic children. Spearman correlation coefficients and $P$ values are indicated $(n=21)$. SP indicates surfactant protein; ALX, area of low reactance; Fres, resonant frequency; $\mathrm{R} 5$ and $\mathrm{R} 20$, airway resistance at $5 \mathrm{~Hz}$ and $20 \mathrm{~Hz}$; X5, reactance at $5 \mathrm{~Hz}$. 
A

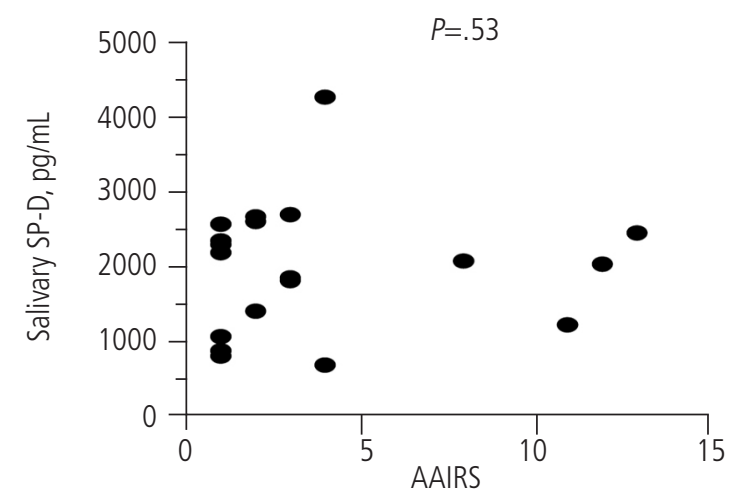

B

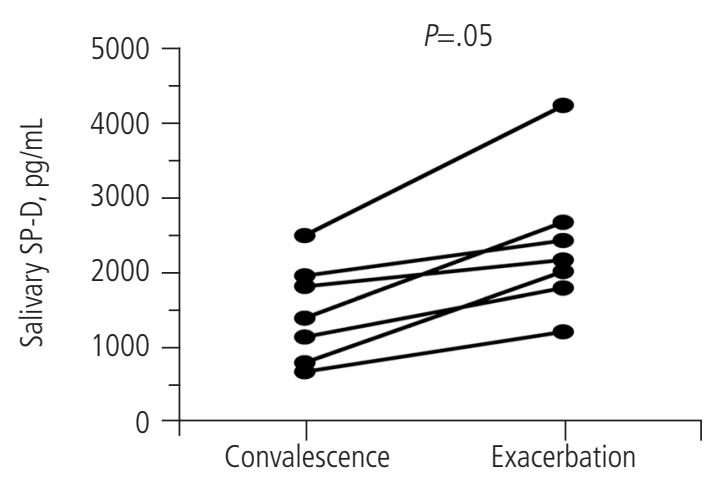

Figure 3. Salivary SP-D levels increase during asthma exacerbation. A, Correlation between salivary SP-D levels and AAIRS. B, Individual differences in salivary SP-D levels during convalescence and acute exacerbation in asthmatic children. SP indicates surfactant protein; AAIRS, acute asthma intensity research score.

regression equations using height, age, and weight, but not gender, as independent variables.

Asymmetric branching of the bronchial tree may cause discrepancies in the anatomic and acoustic characteristics of the central and peripheral airways, and lung ventilation defects are not uniformly distributed in asthmatic lungs [26]; hence, it has been argued that R5-R20 merely represents the frequency-dependence of resistance or the heterogeneity of airway resistance rather than the true resistance of peripheral airways [27]. Historically, however, it has been presumed that R5, R20, and R5-R20 represent the resistances of the whole, central-large, and peripheral-small airways, respectively. In this context, salivary SP-D levels correlated with \%R5-R20 but not \%R20, suggesting that they are associated with airflow limitation in peripheral airways rather than in central airways.

Serum concentrations of SP-D are used in clinical practice as a noninvasive marker of the permeability or integrity of the blood-air barrier in interstitial lung diseases such as interstitial pneumonia [28]. Serum SP-D has been shown to be elevated in allergic patients with a dual asthmatic response after allergen challenge and more pronounced eosinophilic airway inflammation $[24,29]$. Increased permeability of the blood-airspace barrier caused by bronchial inflammation may lead to increased serum SP-D in asthmatics, especially in small airways that have a larger blood-air surface than central airways [30]. Our findings suggest that elevated salivary SP-D levels in asthmatic children might also be caused by small airway inflammation.

Most large salivary molecules are produced by the salivary gland, whereas smaller molecules are transported from the blood to the saliva by passive diffusion, ultrafiltration, or active transport. SP-D is a 43-kDa hydrophilic molecule, and most salivary SP-D is produced by the salivary gland. In fact, salivary SP-D levels do not merely reflect serum levels, as there is only a weak correlation between serum and salivary SP-D levels $\left(\mathrm{r}^{2}=0.2105, P=.1822\right)$. Nonvolatile biomarkers in alveolar fluid can be detected in exhaled breath condensate (EBC). The levels detected in EBC are about $10^{-3}$-fold less than the levels measured in alveolar fluid. If the same dilution factor is applied to SP-D, EBC might contain a few hundred $\mathrm{pg} / \mathrm{mL}$ of SP-D. Since the $\mathrm{EBC}$ volume collected during saliva sampling is negligible compared with the volume of saliva, contamination of SP-D by EBC in salivary samples would likely be insignificant.

Wallaert et al [31] reported that asthmatic patients exhibited T-cell and degranulated mast cell infiltration and increased basement membrane thickness in the minor salivary glands and bronchial mucosa, suggesting that activated $\mathrm{T}$ cells may elicit airway-like inflammation in the salivary glands. Allergen challenge increased SP-D levels in BALF, which correlated with the degree of allergic inflammation in asthmatic lungs [32]. Animal studies in transgenic mice have shown that IL-4 and IL-13 increase SP-D expression [33]. Haczku et al [34] reported that allergen exposure increased SP-D protein levels in an IL-4/IL-13-dependent manner, which in turn, prevented further activation of sensitized $\mathrm{T}$ cells. The allergic inflammatory mechanisms whereby alveolar cells release SP-D into BALF may also enhance SP-D secretion from salivary glands, resulting in increased salivary SP-D levels in asthmatic patients.

Small airway resistance, as assessed by R5-R20, is associated with bronchial hyperresponsiveness, as measured by excessive methacholine-induced bronchoconstriction [35]. Shi et al [36] reported that children with controlled asthma who have increased peripheral airway indices, such as R5R20 values, are at risk of losing asthma control. Although we found no significant correlation between salivary SP-D levels and AAIRS, possibly owing to individual variations, our data suggest that changes in salivary SP-D levels may reflect the degree of asthma exacerbation in the individual patient. Based on its correlation with R5-R20, salivary SP-D may reflect asthma control status.

In conclusion, salivary SP-D may reflect asthmatic inflammation in peripheral small airways and be a useful biomarker for monitoring the degree of exacerbation in childhood asthma.

\section{Funding}

This study was supported by MEXT KAKENHI (Grant number, 15K19606) and the Translational Research Program, University of Fukui. 


\section{Conflicts of Interest}

The authors declare that they have no conflicts of interest.

\section{Previous Presentation}

This study was presented in part as an abstract entitled "Saliva SP-D is a practical marker to identify the peripheral airway inflammation" at the 2015 annual meeting of the American Academy of Asthma, Allergy and Immunology (AAAAI) in Houston, Texas.

\section{References}

1. National Asthma E, Prevention P. Expert Panel Report 3 (EPR3): Guidelines for the Diagnosis and Management of AsthmaSummary Report 2007. J Allergy Clin Immunol 2007;120(5 Suppl):S94-138.

2. Wenzel SE. Asthma phenotypes: the evolution from clinical to molecular approaches. Nat Med 2012;18(5):716-25.

3. Sanchez-Garcia S, Olaguibel JM, Quirce $S$, Ibanez MD, Pediatric Allergy Committee SSOA, Clinical I. Measurement of Lung Function and Bronchial Inflammation in Children Is Underused by Spanish Allergists. J Investig Allergol Clin Immunol 2016;26(2):126-8.

4. Hellinckx J, Cauberghs M, De Boeck K, Demedts M. Evaluation of impulse oscillation system: comparison with forced oscillation technique and body plethysmography. Eur Respir J 2001;18(3):564-70.

5. Bickel S, Popler J, Lesnick B, Eid N. Impulse oscillometry: interpretation and practical applications. Chest 2014;146(3):841-7.

6. Mochizuki H, Hirai $K$, Tabata $H$. Forced oscillation technique and childhood asthma. Allergol Int 2012;61(3):373-83.

7. Batmaz SB, Kuyucu S, Arikoglu T, Tezol O, Aydogdu A. Impulse oscillometry in acute and stable asthmatic children: a comparison with spirometry. J Asthma 2016;53(2):179-86.

8. Ducharme FM, Davis GM. Measurement of Respiratory Resistance in the Emergency Department. Chest 1997;111(6):1519-25.

9. Skylogianni E, Douros K, Anthracopoulos MB, Fouzas S. The Forced Oscillation Technique in Paediatric Respiratory Practice. Paediatr Respir Rev 2016;18:46-51.

10. Frei J, Jutla J, Kramer G, Hatzakis GE, Ducharme FM, Davis GM. Impulse oscillometry: reference values in children 100 to $150 \mathrm{~cm}$ in height and 3 to 10 years of age. Chest 2005;128(3):1266-73.

11. Park JH, Yoon JW, Shin YH, Jee HM, Wee YS, Chang SJ, Sim JH, Yum HY, Han MY. Reference values for respiratory system impedance using impulse oscillometry in healthy preschool children. Korean J Pediatr 2011;54(2):64-8.

12. Hagiwara S, Mochizuki $H$, Muramatsu R, Koyama $H$, Yagi $H$, Nishida Y, Kobayashi T, Sakamoto N, Takizawa T, Arakawa H. Reference values for Japanese children's respiratory resistance using the LMS method. Allergol Int 2014;63(1):113-9.

13. Gochicoa-Rangel L, Torre-Bouscoulet L, Martinez-Briseno D, Rodriguez-Moreno L, Cantu-Gonzalez G, Vargas MH. Values of impulse oscillometry in healthy mexican children and adolescents. Respir Care 2015;60(1):119-27.
14. Hartl D, Griese M. Surfactant protein D in human lung diseases. Eur J Clin Invest 2006;36(6):423-35.

15. Schleh C, Rothen-Rutishauser BM, Blank F, Lauenstein HD, Nassimi M, Krug N, Braun A, Erpenbeck VJ, Gehr P, Hohlfeld JM. Surfactant Protein D modulates allergen particle uptake and inflammatory response in a human epithelial airway model. Respir Res 2012;13:8.

16. Crouch E, Rust K, Veile R, Donis-Keller H, Grosso L. Genomic organization of human surfactant protein D (SP-D). SP-D is encoded on chromosome 10q22.2-23.1. J Biol Chem 1993;268(4):2976-83.

17. Brinker KG, Martin E, Borron P, Mostaghel E, Doyle C, Harding $\mathrm{CV}$, Wright JR. Surfactant protein D enhances bacterial antigen presentation by bone marrow-derived dendritic cells. Am J Physiol Lung Cell Mol Physiol 2001;281(6):L1453-63.

18. Brandt EB, Mingler MK, Stevenson MD, Wang N, Khurana Hershey GK, Whitsett JA, Rothenberg ME. Surfactant protein $D$ alters allergic lung responses in mice and human subjects. J Allergy Clin Immunol 2008;121(5):1140-7 e2.

19. Emmanouil P, Loukides S, Kostikas K, Papatheodorou G, Papaporfyriou A, Hillas G, Vamvakaris I, Triggidou R, Katafigiotis P, Kokkini A, Papiris S, Koulouris N, Bakakos P. Sputum and BAL Clara cell secretory protein and surfactant protein D levels in asthma. Allergy 2015;70(6):711-4.

20. Nayak A, Dodagatta-Marri E, Tsolaki AG, Kishore U. An Insight into the Diverse Roles of Surfactant Proteins, SP-A and SP-D in Innate and Adaptive Immunity. Front Immunol 2012;3:131.

21. Tonnel AB, Janin A, Copin MC, Gosset P, Gosselin B, Wallaert B. Airway-like inflammation of minor salivary glands in bronchial asthma. Int Arch Allergy Immunol 1995;107(1-3):387-8.

22. Arnold DH, Saville BR, Wang W, Hartert TV. Performance of the Acute Asthma Intensity Research Score (AAIRS) for acute asthma research protocols. Ann Allergy Asthma Immunol 2012;109(1):78-9.

23. Global initiative of Asthma (GINA): Global strategy for asthma management and prevention. 2016. Available online: http:// ginasthma.org/

24. Mackay RM, Grainge CL, Lau LC, Barber C, Clark HW, Howarth $\mathrm{PH}$. Airway Surfactant Protein D Deficiency in Adults With Severe Asthma. Chest 2016;149(5):1165-72.

25. Shi Y, Aledia AS, Tatavoosian AV, Vijayalakshmi S, Galant SP, George SC. Relating small airways to asthma control by using impulse oscillometry in children. J Allergy Clin Immunol 2012;129(3):671-8.

26. Altes TA, Mugler JP, 3rd, Ruppert K, Tustison NJ, Gersbach J, Szentpetery $\mathrm{S}$, Meyer $\mathrm{CH}$, de Lange EE, Teague WG. Clinical correlates of lung ventilation defects in asthmatic children. J Allergy Clin Immunol 2016;137(3):789-96 e7.

27. Gonem S, Natarajan S, Desai D, Corkill S, Singapuri $A$, Bradding P, Gustafsson P, Costanza R, Kajekar R, Parmar H, Brightling CE, Siddiqui S. Clinical significance of small airway obstruction markers in patients with asthma. Clin Exp Allergy 2014:44(4):499-507.

28. Hermans $C$, Bernard A. Lung epithelium-specific proteins: characteristics and potential applications as markers. Am J Respir Crit Care Med 1999;159(2):646-78.

29. Koopmans JG, van der Zee JS, Krop EJ, Lopuhaa CE, Jansen $\mathrm{HM}$, Batenburg JJ. Serum surfactant protein $D$ is elevated in allergic patients. Clin Exp Allergy 2004;34(12):1827-33. 
30. Benfante A, Battaglia S, Principe S, Di Mitri C, Paterno A, Spatafora M, Scichilone N. Asthmatics with high levels of serum surfactant protein $D$ have more severe disease. Eur Respir J 2016;47(6):1864-7.

31. Wallaert $B$, Janin $A$, Lassalle $P$, Copin $M C$, Devisme $L$, Gosset $P$, Gosselin B, Tonnel AB. Airway-like inflammation of minor salivary gland in bronchial asthma. Am J Respir Crit Care Med 1994;150(3):802-9.

32. Erpenbeck VJ, Schmidt R, Gunther A, Krug N, Hohlfeld JM. Surfactant protein levels in bronchoalveolar lavage after segmental allergen challenge in patients with asthma. Allergy 2006;61(5):598-604.

33. Qaseem AS, Sonar S, Mahajan L, Madan T, Sorensen GL, Shamji MH, Kishore U. Linking surfactant protein SP-D and IL-13: implications in asthma and allergy. Mol Immunol 2013;54(1):98-107.

34. Haczku A, Cao Y, Vass G, Kierstein $S$, Nath $P$, AtochinaVasserman EN, Scanlon ST, Li L, Griswold DE, Chung KF, Poulain FR, Hawgood S, Beers MF, Crouch EC. IL-4 and IL-13 Form a Negative Feedback Circuit with Surfactant Protein-D in the Allergic Airway Response. J Immunol 2006;176(6):355765.
35. Alfieri V, Aiello M, Pisi R, Tzani P, Mariani E, Marangio E, Olivieri D, Nicolini G, Chetta A. Small airway dysfunction is associated to excessive bronchoconstriction in asthmatic patients. Respir Res 2014;15:86.

36. Shi Y, Aledia AS, Galant SP, George SC. Peripheral airway impairment measured by oscillometry predicts loss of asthma control in children. J Allergy Clin Immunol 2013;131(3):71823.

Manuscript received December 27, 2016; accepted for publication May 30, 2017.

\section{Hiroki Murai}

23-3 Shimoaizuki, Matsuoka, Eiheiji-cho, Yoshida-Gun, Fukui 910-1193 Japan

E-mail: himurai@u-fukui.ac.jp 